\title{
Political participation of older adults in Scandinavia - the civic voluntarism model revisited? A multi-level analysis of three types of political participation
}

\author{
By Mikael NyGÅrd* E GunborG JAKOBSSON*
}

\begin{abstract}
This article examines political participation among older adults in Österbotten, Finland, and Västerbotten, Sweden. Two specific hypotheses are tested. First, we anticipate that older adults are loyal voters but less avid in engaging in politics between elections. Second, we expect individuallevel resources to explain why older people participate in politics.

The article offers two contributions to the literature on political participation of older adults. First, it corroborates earlier findings by showing that older adults indeed have a higher inclination to vote than to engage in political activities between elections, but it also shows that the latter engagement is more diversified than one could expect. Second, although the findings largely support the resource model, they suggest that we need to consider also other factors such as the overall attitude towards older people.

Keywords: political participation, older adults, resource theory, civic voluntarism, Västerbotten, Österbotten.

* Mikael Nygård and Gunborg Jakobsson, Department of Social Sciences, Åbo Akademi University, Vasa, Finland
\end{abstract}


International Journal of Ageing and Later Life

\section{Introduction}

The political participation of older adults in Western democracies has received increasing attention during the last decades, as a consequence of demographic transformations and a growing elderly electorate.

Notwithstanding this growing interest, the research on political participation of older adults is still in an initial phase. Research has so far showed how age influences political behaviour (e.g. Franklin 2004; Wass 2008) or how older people differ from younger cohorts in this respect (Goerres 2009; Quintilier 2007), but we still do not know much about the deeper meanings of political engagement for older people. For example, according to the well-established resource theory of civic voluntarism (Verba et al. 1995), political participation of older adults can be seen as a function of mobilising factors, such as high education or extensive social networks (Goerres 2009; Nygård \& Jakobsson 2011). However, it is also likely that other factors, such as the overall wellbeing, play a role for their inclination to participate in civic activities (cf. Schyns 1998; Veenhoven 1995). Moreover, country-specific factors such as welfare-institutional structures or cultural characteristics are likely to shape these relationships and create different participatory patterns in different counties.

This article examines political participation among older adults in Finland and Sweden with the help of cross-sectional survey data from two specific regions, Österbotten in Western Finland and Västerbotten in North-Eastern Sweden. The data allow us not only to examine political participation in a welfare-state setting that is known for its universal features but also to compare how it differs between the two countries. Moreover, due to the multi-disciplinary character of the data, it becomes possible to test the resource model against other factors, which in turn provides a deeper understanding of the phenomenon at hand. Accordingly, the aim of the article is to analyse patterns of political participation among older adults in two Scandinavian regions and to test different explanative models for this participation. Two specific hypotheses are tested. First, we anticipate that older adults are loyal voters but less avid to engage in politics between elections. Second, we expect individual-level resources to explain why older people participate in politics. 
Political participation of older adults in Scandinavia

\section{Definitions and Literature Review}

As such, chronological age has no self-evident effects on political participation. Nevertheless, it tends to influence political behaviour through the roles that a person plays in different life stages. The concept of older adults is not straightforward since old age has different meanings in different cultures and undergoes change over time (Westerhof \& Tulle 2011; Wilson 2000). Here, we choose to define older adults as persons aged 60 or more, since it is in accordance with earlier research in this field (cf. Goerres 2009).

Also, the concept of political participation is problematic due to its many forms and changing character. As a phenomenon, it can refer both to more official activities within the boundaries of representative democracy and to activities that are more direct, more spontaneous and not confined to formal arenas of political action (Barnes et al. 1979; Kaase 1999). It can also relate either to voluntary, non-professional activities or activities that are to be seen as professional or bureaucratic in accordance with the Weberian notion "Politik als Beruf" (cf. Verba \& Nie 1972). Different types of political participation function differently when it comes to the ways that they convey or manifest positions or individual standpoints, that is, how they affect the general opinion or policy-makers (Goerres 2010; Verba et al. 1978, 1995). For example, while voting can be seen as an efficient way for the average citizen to exercise pressure over politicians, but as a less efficient way of conveying preferences, a petition or a demonstration usually works the other way around. Here, political participation is defined as the individual, non-professional and voluntary participation in activities that aim, directly or indirectly, at influencing political outcomes, changing the institutional premises for politics or affecting the selection of personnel or their choices (cf. Barnes et al. 1979: 59; Verba \& Nie 1972: 2; Verba et al. 1995: 38). This definition precludes, for example, paid political work, lobbying or running for office as well as activities that merely represent attentiveness or interest in politics (e.g. reading newspapers) or an ambition to express oneself to make a moral statement (e.g. wearing a badge). Also, the engagement in voluntary organisations, such as pensioner's organisations or theatre associations, falls outside this definition. 
International Journal of Ageing and Later Life

The international literature has suggested a number of classifications of political participation, one early and influential version being the distinction between conventional and non-conventional types of participation (Barnes et al. 1979). Put simply, participation that pertains to the arena of representative democracy, such as campaigning for a candidate or voting, was here seen as a conventional action whereas an activity outside this arena (such as protesting) was seen as non-conventional. This distinction may have been relevant in the 1960s, 1970s and even the 1980s, but is no longer up to date. Therefore, another distinction has gained ground that distinguishes between institutionalised and non-institutionalised political participation (Goerres 2009, 2010). The first category - institutionalised participation - refers to organised, formal forms of participation such as voting, whereas the other category - non-institutionalised participation relates to more spontaneous, informal forms of participation outside the "institutionalised" political sphere, such as protesting or boycotting (cf. Goerres 2010; Kaase 1999; Stolle \& Micheletti 2006). Also, there are studies that suggest that the non-institutionalised category is too wide to successfully capture all nuances of participation between elections since boycotting - for instance - partly represents another kind of political statement than for example contacting (Bengtsson \& Chistensen 2009; Nygård \& Jakobsson 2011; Stolle \& Micheletti 2006; Stolle et al. 2005).

Judging from the evidence provided by previous research it seems that institutionalised participation, notably voting, is today losing ground in most western democracies while non-institutionalised types of participation are gaining terrain, not least among younger citizens but also among new cohorts of older people (e.g. Blais et al. 2004; Campbell 2003; Dalton 2006, 2008; Franklin 2004; Goerres 2010; Jennings \& Markus 1988; Kaase 1999; Norris 2002; Putnam 2000). This transformation has been seen as an expression of changing value structures (Inglehart 1990), eroding trust in politics (Dalton 2004) or changes in the overall political integration, especially of younger generations (Blais et al. 2004; Dalton 2008; Quintelier 2007). The growing acceptance of non-institutionalised participation on the other hand has, among other things, been related to changes over time in political socialisation. Allegedly, where and when one is born matters for one's political behaviour. The political culture and the social norm 
structure that was prevailing during our impregnable years of youth are likely to have a lasting impact on us as political beings (Butler \& Stokes 1983; Rose \& McAllister 1990).

One interesting feature in the research on ageing and political participation is that age is often treated as an independent variable alongside others, which has generated many volumes on how participation, and voting in particular, changes over the life course and how older persons differ from young in this respect, but very few studies on what political participation actually means to older persons and how it relates to other spheres of their lives have been done (cf. Nygård \& Jakobsson 2011). One of the most valuable insights generated from previous research is that voting generally is lower when we are young, rises when we become middle-aged and stays high until the frailty of very old age starts to refrain us from voting (e.g. Franklin 2004; Verba \& Nie 1972; Wass 2008; Wolfinger \& Rosenstone 1980). Another is that older people tend to be less likely than younger people to engage in non-institutionalised activities (e.g. Barnes et al. 1979; Campbell 2003; Goerres 2009; Jennings \& Markus 1988; Norris 2002). However, such findings are not always unequivocal. When it comes to the phenomenon of writing letters to representatives, for instance, Campbell $(2002,2003)$ found no clear differences between older and younger American citizens. Similarly, Kam (2000) found very little support for the thesis that non-institutionalised activities are rarer among older people in Hong Kong. Although these examples represent merely a small fraction of the evidence from this genre of research, they suggest that the patterns and determinants of political participation of older adults may be strongly circumstanced by geographical, cultural, historical as well as socio-political factors (Wilson 2000). Therefore, there is a need for a wider multi-disciplinary political gerontology (cf. Cutler 1977) that not only examines the finer nuances and driving forces of political participation of older persons and relates it to their lives and living conditions in general but also situates these patterns and relationships in unique and country-specific settings.

When it comes to the question as to why older persons engage in politics, we find that the same factors that explain political participation in general also work fine with respect to older persons (cf. Campbell 2003). One of the most influential explanative models in this respect is the 
International Journal of Ageing and Later Life

resource model of civic voluntarism (Verba et al. 1995). In their pioneering work on political participation, Verba and Nie (1972) stated that participation is more likely among persons with higher levels of socioeconomic resources (such as education or income) than among others. Also Wolfinger and Rosenstone (1980) found evidence supporting this thesis as education in particular was found to have a triggering effect on voting. The civic voluntarism model later developed by Verba et al. (1995) continued along these lines. According to the model, participation in politics is stimulated by three main groups of "participatory" factors: socio-economic resources, engagement and mobilisation. Education, political skills and income serve as examples of socio-economic resources that facilitate participation. Engagement, on the other hand, relates to one's interest in politics, political knowledge and belief in the capacity to influence politics. Mobilisation, finally, refers to the stimulating effects that rise from interaction with other persons in social networks, such as one's affiliation with voluntary organisations or workplace communities (Verba et al. 1995).

The engagement dimension in this model has also sometimes been referred to as political efficacy, which is a two-fold concept. Internal political efficacy relates to the belief that one can influence politics whereas external efficacy relates to the belief that politicians actually care about one's opinions (e.g. Dalton 2008). Another concept that comes close to the engagement dimension is political trust (also called institutional trust or political support), which generally refers to the trust that an individual has in the political system, politicians or political institutions (Dalton 2008; Easton 1975). Similarly, the mobilisation dimension has often been considered in terms of social capital (e.g. Bäck 2011; Teorell 2003). Advocates of the "social capital school", most notably Robert Putnam (2000), have suggested that the mobilising factors in a person's social life mainly consist of a cognitive and a structural aspect. Whereas the former aspect relates to interpersonal trust, the latter relates to a person's engagement in voluntary organisations. However, the impact of social capital is likely to be less important for non-institutionalised forms of participation (Kaase 1999), as such activities are often characterised by some sort of dissent and may be fuelled by a lack of trust in institutionalised forms of civic engagement. 
The resource model has been tested on older adults on a number of occasions and has largely proven robust (e.g. Campbell 2003; Goerres 2009; Nygård \& Jakobsson 2011). For instance, in a recent paper on older Finns, Nygård \& Jakobsson (2011) found support for the stimulating effect of socio-economic resources and mobilisation on both voting and noninstitutionalised political activities whereas the effects of engagement, on the other hand, were found to be almost non-existent. In another analysis of the relationship between voting and ageing in Europe, Goerres (2007, 2009) found support for not only all three dimensions of the resource model but also found that good health, long residential duration, living with a partner as well as a strong sense of duty are important predictors in this respect. Some authors have also suggested that negative old-age attitudes may hamper the participation of older adults (e.g. Cuddy et al. 2005), whereas others argue that older adults tend to become more politically active if they feel that their interests are threatened (Campbell 2002, 2003).

To sum up, on the basis of this literature review older people in Scandinavia are likely to be eager voters but less avid with respect to participation between elections. Moreover, political participation is expected to be a function of the level of socio-economic resources as well as engagement and mobilisation. How useful is then the resource model when applied in a specific geographical and welfare-institutional setting such as the Scandinavian countries? Older people in these countries are far better educated, enjoy far better health and receive more generous (income-related) pensions than any generation before them (cf. NCM 2010; Sundström 2009). Furthermore, poverty rates among retired people in Finland and Sweden are very low when compared internationally (e.g. Smeeding \& Sandström 2005). Last, but not least, both countries share a legacy of stable political institutions, long-lasting majority coalitions and early adopted and widely distributed political rights that have also had a positive effect on gender equality (Anttonen 2005; Einhorn \& Logue 2003). One plausible effect is a weaker impact of wealth on political participation than in countries such as the United States, where income among retired people is more unevenly distributed (Campbell 2003). Another plausible outcome is a less evident role of "social capital" for participation than in the United States or European countries in general, since encompassing 
International Journal of Ageing and Later Life

welfare regimes with individualised social rights are often believed to have an undermining effect on the overall level of social capital (Putnam 2000). Furthermore, gender differences in political participation can be expected to be small, although older women are generally believed to be less active in politics than men due to different socialisation processes (Inglehart \& Norris 2003; Welch 1977). Finally, since the cohorts in this study reached their statutory voting age (21 years) during post-war periods (the 1950s and 1960s) when turnout rates in Finland and Sweden were exceptionally high in historical comparison (Einhorn \& Logue 2003), we can expect this to manifest itself through high levels of voting participation.

\section{Data and Empirical Design}

\section{Data and Study Population}

The two hypotheses of the article have been analysed with the help of data from a cross-sectional survey that was conducted in 2010 as part of an inter-regional research project, the GERDA Bothnia project (see GERDA 2012). ${ }^{1}$ The overall aim of this multi-disciplinary project was to map living and health conditions of older adults living in the Bothnia region, that is, on both sides of the Gulf of Bothnia, in Västerbotten in Sweden (15 municipalities/211,884 inhabitants) and in Österbotten in Finland (17 municipalities/178,000 inhabitants). As part of the project, in 2010, a questionnaire was sent to all people aged 65 (born 1945), 70 (born 1940), 75 (born 1935) and 80 (born 1930) living in rural municipalities in this area, as well as to every second person in the most populous town in Österbotten, Finland, and to every third person residing in the two most populous towns in Västerbotten, Sweden. The sample was made on the basis of the official population register in Finland and the official tax authority in Sweden (Herberts 2011).

Finnish is the majority language in Finland, but there is also a Swedishspeaking minority, which apart from the Aland archipelago resides predominantly in the region of Österbotten. The Finnish questionnaires were

\footnotetext{
${ }^{1}$ The acronym GERDA stands for Gerontological Regional Database and Resource Centre (GERDA 2012).
} 
sent in Finnish to Finnish-speaking Finns and in Swedish to Swedishspeaking Finns on the basis of their reported mother tongue in the Finnish population register. In the questionnaires the respondents were also asked to report their mother tongue.

In September-October 2010, a total of 10,696 questionnaires were sent out to the persons in the sample. After reminders, a total response rate of $64 \%(n=6838)$ was obtained. The questionnaire was answered by 3779 persons in Sweden and 3059 in Finland, resulting in a total response rate of 70.7 and $57.2 \%$, respectively. The response rate was higher among the two younger age groups (66\%) than those aged 75 and 80 (62 and 59\% respectively). Furthermore, the survey generated a lower response rate among the Finnish-speaking Finns (52.9\%) than among Swedish-speaking Finns (61.5\%). In most surveys directed to older people, the dropout rate is generally higher among those with frailty and those in care. In this sample, only a small proportion of the respondents reported poor health $(4.2 \%)$ or lived in a service facility for seniors $(1.3 \%)$.

\section{Outcome Variables}

The analysis used 11 items on political participation frequently employed in similar research (e.g. Barnes et al. 1979; Goerres 2009; Verba et al. 1995). ${ }^{2}$ On the basis of descriptive and dimensional analyses of these items, three outcome variables (indices) were constructed for the sake of the explanative analysis. The first outcome variable, voting, is based on the reported voting in municipal, parliamentary and presidential (Finland) or county council (Sweden) elections, and thus refers to the institutionalised dimension of political participation (Cronbach's Alpha $[\mathrm{CA}]=0.830$ ).

\footnotetext{
${ }^{2}$ The original items were: "Did you vote in the latest municipal, parliamentary, European, church council, presidential/county council election?" (yes, no, do not know), "Have you during the last five years engaged in the following activities: contacted a civil servant or politician, appealed against a decree launched by authorities, written a letter to the editor/an article in a news paper/journal, signed a petition, participated in a demonstration, used your power as a consumer for boycotting a product, a company or a country?" (yes, many times, yes, occasionally, no, do not remember).
} 
International Journal of Ageing and Later Life

The second variable, influencing, relates to contacting politicians, appealing against decisions and writing letters to the press $(C A=0.600)$. The third outcome variable, protesting, is an index of boycotting, signing petitions and demonstrating $(\mathrm{CA}=0.590)$. Given the fact that the 11 questions on participation have been extensively tested in earlier research and indices generally prove more valid measures than separate items (e.g. Bohrnstedt \& Knoke 1982: 360-362), this procedure can be seen as more reliable than using separate items as outcome variables. It also helps to rectify the wellknown problem of overestimation of voting behaviour (e.g. Martikainen et al. 2005: 654), which is likely to be even more aggravated when we are dealing with older persons.

\section{Individual-Level Variables}

Three sets of individual-level independent variables were used (see Table 1). The first set of variables can be said to represent the resource model discussed above and includes income (less than $1000 € /$ month, $1001 €$ or more), education (under 10 years, 10 years or more), political trust (low, high), political efficacy (low, high), party membership (no, yes), political interest (low, high), membership in voluntary associations (low, high) and interpersonal trust (low, high). ${ }^{3}$ The last two variables were summative

\footnotetext{
${ }^{3}$ The original items were: Income: "What is your monthly income before taxes?" $(0-500 €, 501-1000 €, 1001-1500 €$, more than $1500 €)$, Education: "How many years of school do you have?" (Continuous), Political trust: "How is your confidence in parliament and government?" (strong, neither strong nor weak, weak, cannot say), Internal political efficacy: "I feel strong and influential in society" (totally agree, partly agree, do not agree at all), Party membership: "Are you member in a political party?" (yes actively, yes passively, no not member), Political interest: "Do you regularly watch programs/news on societal issues on TV?" (yes, no), Membership in voluntary associations: summative index based on the involvement in sports/outdoor, religious, social or health, cultural, senior, housing or local community, relative/patient or other kinds of associations, Interpersonal trust: "How much confidence do you have in the following persons / . . / friends and neighbours?" $(1=$ much, $2=$ neither much nor little, $3=$ little, $4=$ cannot say).
} 
Table 1. The distribution of respondents (in\%) by variable category and country $(\mathrm{N}=6838)$

\begin{tabular}{|c|c|c|c|c|}
\hline & \multicolumn{2}{|c|}{$\begin{array}{l}\text { Finland } \\
(\mathrm{N}=3059)\end{array}$} & \multicolumn{2}{|c|}{$\begin{array}{l}\text { Sweden } \\
(\mathrm{N}=3779)\end{array}$} \\
\hline & $\%$ & $\%$ & $\%$ & $\%$ \\
\hline \multicolumn{5}{|l|}{ Outcome variables } \\
\hline $\begin{array}{l}\text { Voting (low, voted in all } \\
\text { three elections) }\end{array}$ & 17.8 & 82.2 & 19.3 & 80.7 \\
\hline $\begin{array}{l}\text { Influencing (low, participated } \\
\text { in one activity) }\end{array}$ & 74.0 & 26.0 & 64.3 & 35.7 \\
\hline $\begin{array}{l}\text { Protesting (low, participated } \\
\text { in one activity) }\end{array}$ & 67.2 & 32.8 & 59.8 & 40.2 \\
\hline \multicolumn{5}{|l|}{ Individual-level independent variables } \\
\hline \multicolumn{5}{|l|}{ Resource-model variables } \\
\hline Income $(0=$ low, $1=$ high $)$ & 31.5 & 68.5 & 27.6 & 72.4 \\
\hline $\begin{array}{l}\text { Education }(0=0-9 \text { years, } 1=10 \text { years } \\
\text { or more) }\end{array}$ & 45.2 & 54.8 & 50.5 & 49.5 \\
\hline Political trust $(0=$ low, $1=$ high $)$ & 87.2 & 12.8 & 77.9 & 22.1 \\
\hline Political efficacy $(0=$ low, $1=$ high $)$ & 43.5 & 56.5 & 45.8 & 54.2 \\
\hline Member in a party $(0=$ no, $1=$ yes $)$ & 71.1 & 28.9 & 79.6 & 20.4 \\
\hline Political interest $(0=$ low, $1=$ high $)$ & 7.9 & 92.1 & 5.3 & 94.7 \\
\hline $\begin{array}{l}\text { Voluntary associations }(0=\text { low, } \\
1=\text { high })\end{array}$ & 82.3 & 17.7 & 79.4 & 20.6 \\
\hline Interpersonal trust $(0=$ low, $1=$ high $)$ & 32.0 & 68.0 & 27.6 & 72.4 \\
\hline \multicolumn{5}{|l|}{ Value variables } \\
\hline Sense of duty $(0=$ weak, $1=$ strong $)$ & 46.1 & 53.9 & 45.8 & 54.2 \\
\hline Religiosity $(0=$ weak, $1=$ strong $)$ & 14.2 & 85.8 & 34.2 & 65.8 \\
\hline \multicolumn{5}{|l|}{ Well-being variables } \\
\hline Life quality $(0=$ low, $1=$ high $)$ & 72.7 & 27.3 & 66.0 & 34.0 \\
\hline Self-rated health $(0=$ poor, $1=$ good $)$ & 40.4 & 59.6 & 33.2 & 66.8 \\
\hline Health care trust $(0=$ low, $1=$ high $)$ & 48.8 & 51.2 & 53.9 & 46.1 \\
\hline $\begin{array}{l}\text { Old-age attitude }(0=\text { positive, } \\
1=\text { negative })\end{array}$ & 56.4 & 43.6 & 60.0 & 40.0 \\
\hline \multicolumn{5}{|l|}{ Control variables } \\
\hline Age group $(0=65$ years, $1=70$ years $)$ & 39.8 & 22.2 & 36.4 & 25.9 \\
\hline $\begin{array}{l}\text { Age group, cont. }(3=75 \text { years, } 4=80 \\
\text { years) }\end{array}$ & 21.2 & 16.8 & 20.7 & 17.0 \\
\hline Gender $(0=$ female, $1=$ male $)$ & 55.9 & 44.1 & 52.4 & 47.6 \\
\hline
\end{tabular}




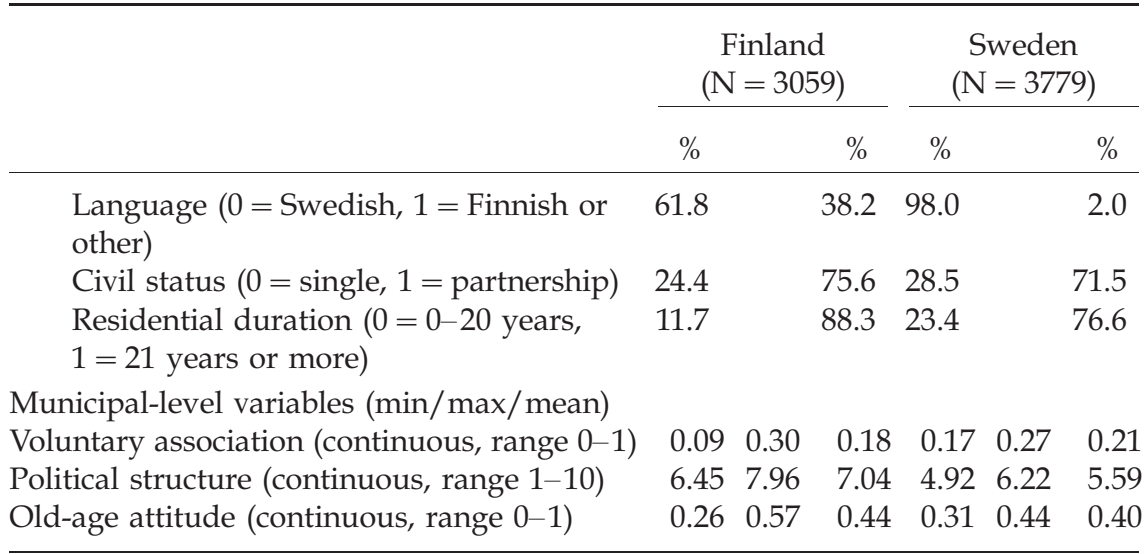

indexes calculated on the activity in voluntary association other than political parties, as well as trust in friends and neighbours. ${ }^{4}$

The second set of independent variables assesses the value structure of the respondents and includes two variables; sense of duty (weak, strong) and religiosity (no, yes). ${ }^{5}$ The third set relates to the overall wellbeing of the respondent and includes the variables life quality (weak, strong), self-rated

\footnotetext{
${ }^{4}$ The voluntary association index was constructed on the basis of how many associations a person was a member of and how actively he or she engaged in them. For each association, active membership generated the value 2, passive membership 1 and no membership the value 0 . These numbers were then added together into a total value of associational membership for each respondent and then dichotomised $(0-2=$ "low", 3 or higher $=$ "high"). Similarly, the interpersonal trust index was constructed by first calculating the level of trust ("high" =1, "low", "neither high nor low" and "cannot say" =0) for each item separately and them adding them together into a dichotomised variable $(2=$ "high", 1 or $0=$ "low").

${ }^{5}$ The original items were: Sense of duty: index of the questions "I see the things that I have planned through" / I see myself as a part of a whole" / I I am a person that can be trusted" /"I know my responsibility" and Religiosity: "Do you believe in God or a higher force?" (yes, no, don't know).
} 
Political participation of older adults in Scandinavia

health (poor, good), trust in health care (low, high) and subjective old-age attitude (positive, negative). ${ }^{6}$

Most of the variables in the first and second set have been used in previous research on political participation (cf. Bäck 2011; Nygård \& Jakobsson 2011). ${ }^{7}$ Sense of duty has been found to be an important predictor of voting (Goerres 2009) but is not likely to have a strong influence on non-voting activities. Religiosity, in turn, reflects important aspects of a person's value structure. The variables in the third set, on the other hand, have not as far as we know previously been used for explaining political participation of older adults, except for health. Life quality assesses the effect of the overall wellbeing of a person and can be expected to have a positive influence on participation (Frey et al. 2004; Lane 1988; Stutzer \& Frey 2006; Veenhoven 1995). Health care trust is used as a proxy for the overall trust in the welfare state, and tests whether concern about welfare services affect political participation (cf. Campbell 2003). The variable old-age attitude assesses the role that experiences of negative attitudes towards older adults play for political participation (cf. Campbell 2003; Cuddy et al. 2005).

\section{Control Variables}

Age (65, 70, 75, 80 years), (male) gender, language (Swedish, Finnish or other), civil status (single, partnership) and duration of residence (maximum 20 years,

\footnotetext{
${ }^{6}$ The original items were: Life quality: index of the questions "How happy or unhappy do you feel at the moment?" (very happy, fairly happy, hard to say, fairly unhappy, very unhappy)/"How meaningful do you find your life right now?" (very meaningful, fairly meaningful, hard to say, fairly meaningless, very meaningless), Self-rated health: In general, how would you say your health is? (excellent, very good, good, fair, poor), Trust in health care: "How is your confidence in the health care system in your home municipality?" (strong, neither strong nor weak, weak, cannot say), Subjective old-age attitude: "According to your opinion, what is the general attitude towards older people within politics?" (positive, neutral, negative, cannot say).

${ }^{7}$ The dichotomisation of the independent variables means a certain loss of variance, but increases the sub sample sizes, which helps to create enough large intra-group variance in order to make regression analysis fruitful.
} 
International Journal of Ageing and Later Life

21 years or longer) were used as control variables. The last variable serves as a proxy for a person's social integration; the longer one has lived in a place, the more likely one is to adhere to social norms (Goerres 2009).

\section{Municipal-Level Variables $(N=32)$}

Three variables, membership in voluntary associations, political structure and the subjective old-age attitude, were used to assess the effect of contextuallevel characteristics for the 32 municipalities. The variables were calculated as aggregated group means (with continuous values varying between 0 and 1 , or between 1 and 10 as in the case of political structure, where higher values indicate a more rightist value structure) on the basis of their individual-level analogues and can be said to assess the effect of the overall social norm of participation (associational membership), the overall ideological structure (overall positioning on the left-right axis) as well as the perceived overall attitude towards older adults (old-age attitude).

\section{Analyses}

The data was analysed with the STATA 10 software package. Initially, the 11 types on participation were analysed separately for both countries to discern overall patterns and to discern the amount of variance in political participation between the two countries. On the basis of factor analyses, three outcome variables were constructed: voting, influencing and boycotting. These variables were then analysed by using two-level multivariate logistic regression analysis (xtmelogit), since this enabled us not only to compare the role of the civic voluntarism model to other explanations but also to compare the impact of individual-level variables (level 1) to that of municipal-level characteristics (level 2). We chose to use municipal-level variables instead of country-level aggregates since preliminary analyses (not reported here) showed that there was not enough variance on level three (the country level) to make such a modelling strategy meaningful. Therefore, the subsequent analysis concentrated only on the individual and municipal level.

Four models were fitted for each outcome variable, the first model being an "empty" model providing a baseline estimate of the level-2 variance $\left(\sigma_{u}^{2}\right)$ as well as the variance partition coefficients (VPC) for level two 
Political participation of older adults in Scandinavia

according to Snijders and Bosker's (2001) formula. The second model assesses the effects of individual-level variables, the third the effects of contextual-level variables. The fourth and final model is a full model that includes all variables (also control variables). In addition to each regression model we also controlled for possible individual-level as well as cross-level interaction effects.

\section{Findings}

Table 2 shows participation levels for 11 political activities by country and age group. Three interesting observations can be made. First we find a higher level of engagement with respect to institutionalised than noninstitutionalised political activities. The average percentages for the former superseded the latter by 50 in some cases. But we can also detect variation within these two broad categories. While around $90 \%$ reported that they had voted in the latest presidential/county council, parliamentary or municipal elections, a much smaller proportion reported having voted in the elections to the European parliament or church council elections. Similarly, letters to politicians or officials, petitions or boycotts were more common than for example demonstrations.

Second, we see that participation differs between age groups. While the reported voting levels differed only slightly across age groups, noninstitutional activities were generally much rarer in older age groups than in younger ones. One exception was church council voting, that is generally higher among older respondents.

Third, Table 2 (and also Table 1) shows that there are some interesting differences in political participation between Finnish and Swedish older adults. While older adults in Finland reported a somewhat higher average level of institutionalised participation, the opposite seemed to be true for non-institutionalised participation. But there were also some differences between the countries as to the reported participation levels of each cohort. For example, while voting (church council elections not included) differed slightly across age groups in Sweden, the 80-year-olds in Finland generally reported lower engagement than other age groups. This can be a result of many things, but one plausible cause is that the Finnish cohorts differ more in political socialisation than do the Swedish. The pre-war cohorts 
International Journal of Ageing and Later Life

Table 2. Participation in different types of political activities (as a percentage) by country and age group $(\mathrm{N}=6838)$

\begin{tabular}{|c|c|c|c|c|c|c|c|c|}
\hline \multirow[b]{2}{*}{ Type of participation } & \multicolumn{4}{|c|}{ Finland $(\mathrm{N}=3059)$} & \multicolumn{4}{|c|}{ Sweden $(\mathrm{N}=3779)$} \\
\hline & $\begin{array}{l}65 \\
\%\end{array}$ & $\begin{array}{l}70 \\
\%\end{array}$ & $\begin{array}{c}75 \\
\%\end{array}$ & $\begin{array}{l}80 \\
\%\end{array}$ & $\begin{array}{l}65 \\
\%\end{array}$ & $\begin{array}{l}70 \\
\%\end{array}$ & $\begin{array}{l}75 \\
\%\end{array}$ & $\begin{array}{c}80 \\
\%\end{array}$ \\
\hline Voted in municipal election ${ }^{a}$ & 92.5 & 93.4 & 92.3 & 88.9 & 93.4 & 93.1 & 91.5 & 92.2 \\
\hline $\begin{array}{l}\text { Voted in parliamentary } \\
\text { election }^{\mathrm{a}}\end{array}$ & 93.7 & 92.0 & 92.9 & 89.2 & 94.5 & 94.0 & 92.9 & 92.0 \\
\hline Voted in EU election $^{\mathrm{a}}$ & 75.6 & 74.5 & 72.8 & 65.8 & 55.5 & 59.8 & 54.3 & 52.9 \\
\hline $\begin{array}{l}\text { Voted in church council } \\
\text { election }^{\mathrm{a}}\end{array}$ & 36.2 & 45.3 & 53.0 & 55.8 & 40.7 & 49.4 & 54.4 & 61.2 \\
\hline $\begin{array}{l}\text { Voted in presidential/ } \\
\text { county council election }\end{array}$ & 92.8 & 91.9 & 92.3 & 88.2 & 89.7 & 88.8 & 88.2 & 86.2 \\
\hline Average & 78.16 & 679.42 & 80.66 & 77.58 & 74.76 & 677.02 & 76.26 & 76.90 \\
\hline $\begin{array}{l}\text { Contacted a politician or an } \\
\text { official }^{\text {b }}\end{array}$ & 31.3 & 21.9 & 19.8 & 15.7 & 43.1 & 32.7 & 31.1 & 25.2 \\
\hline $\begin{array}{l}\text { Appealed against a } \\
\text { decision }^{\mathrm{b}}\end{array}$ & 10.3 & 7.7 & 5.1 & 4.9 & 13.0 & 9.4 & 6.9 & 6.0 \\
\hline Wrote a letter to the press ${ }^{\mathrm{b}}$ & 12.0 & 9.2 & 8.2 & 6.0 & 12.0 & 10.8 & 9.9 & 7.8 \\
\hline Signed a petition ${ }^{\mathrm{b}}$ & 28.8 & 21.9 & 18.0 & 13.9 & 38.6 & 31.8 & 27.0 & 20.6 \\
\hline $\begin{array}{l}\text { Participated in a } \\
\text { demonstration }^{\mathrm{b}}\end{array}$ & 1.6 & 1.4 & 1.8 & 2.1 & 8.9 & 7.4 & 6.5 & 6.3 \\
\hline Participated in a boycott ${ }^{\mathrm{b}}$ & 28.9 & 23.5 & 21.1 & 14.2 & 33.2 & 26.4 & 20.6 & 17.1 \\
\hline Average & 18.81 & 114.27 & 712.33 & 9.47 & 24.80 & 19.75 & 17.00 & 18.83 \\
\hline $\mathrm{N}$ & 1189 & 651 & 608 & 465 & 1315 & 905 & 718 & 566 \\
\hline
\end{tabular}

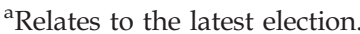

${ }^{b}$ Relates to the previous 5-year period and the share of respondents that had engaged once or several times in the particular activity. The proportions for each variable are based on the number of valid cases.

(notably those born 1930) reached their statutory voting age in the early 1950s, when the war experiences were still fresh and the shadow of Soviet influence was still hanging tight over post-war Finland. By contrast, later cohorts became politically active in a period (the 1960s) when politics had become rejuvenated through the New Left and the Women's movement (cf. Nousiainen 1998). These changing historical contexts are likely to have provided different models of political socialisation for the 
"impressionable" first-time voters of that period (Blais et al. 2004; Franklin 2004; Rose \& McAllister 1990).

Although the findings so far largely confirm our expectations that older Scandinavians are more likely to vote than to engage politically between elections, it does not however provide a clear-cut picture. Rather, the results suggest a more modulated picture of older adults as political beings since a considerable proportion of the respondents, notably Swedish persons in their 60s or early-70s, reported higher engagement in politics between elections at the same time as some persons had refrained from any political activity whatsoever. Moreover, these patterns are likely to become less distinct in the future since future cohorts of older adults probably share other types of political preferences and social norms than do today's older adults (cf. Blais et al. 2004; Dalton 2008; Goerres 2009; McManus 1996; Rose \& McAllister 1990).

To obtain an aggregated picture of political participation among older adults an explorative factor analysis of the 11 dimensions in Table 2 was performed (see Table 3). As shown in Table 3, the factor analysis revealed three underlying dimensions of political participation.

The factor loadings for the first dimension, voting, were strong in relation to voting in municipal, parliamentary and presidential elections (in Finland) or county council elections (in Sweden), but not church council and European elections, and can be said to represent institutionalised political participation (Barnes et al. 1979). The second dimension, influencing, loaded strongly on contacting, appealing against decisions and decrees as well as writing letters to the editor, and can be said to represent a type of political participation that "works the system from within", for example, by using the Internet as a channel (cf. Bengtsson \& Christensen 2009). The third dimension, protesting, on the other hand, represents another type of engagement rationale that is likely to work just as well within representative democracy as outside it. This dimension of political participation loaded strongly on signing petitions, demonstrating and boycotting, and can therefore be said to catch an element of "open protest" that is more often associated with young and middle-aged persons than older adults (Barnes et al. 1979; Goerres 2009, 2010; Jennings \& Markus 1988; Quintilier 2007; Rosenstone \& Hansen 1993). 
International Journal of Ageing and Later Life

Table 3. Dimensions of political participation among older adults $(\mathrm{N}=6838)$

\begin{tabular}{lrrr}
\hline & \multicolumn{3}{c}{ Dimensions } \\
\cline { 2 - 4 } Type of activity & \multicolumn{1}{c}{1} & \multicolumn{1}{c}{2} & \multicolumn{1}{c}{3} \\
\hline Voted in the latest municipal election & .863 & .066 & -.052 \\
Voted in the latest parliamentary election & .862 & .086 & -.054 \\
Voted in the latest EU election & .570 & .023 & .199 \\
Voted in the latest church council election & .500 & -.058 & .146 \\
Voted in latest presidential/county council election & .827 & .059 & .015 \\
Contacted a politician or an official & .050 & .744 & .210 \\
Appealed against a decision & .012 & .817 & .023 \\
Wrote a letter to the press & .038 & .625 & .291 \\
Signed a petition & .111 & .231 & .708 \\
Participated in a demonstration & .028 & .186 & .642 \\
Boycotted a product, company or country & .065 & .054 & .706 \\
Eigenvalue & 2.768 & 1.722 & 1.608 \\
\% of variance & 25.16 & 15.66 & 14.62 \\
\hline
\end{tabular}

Note. The table reports factor loadings generated by principal component analysis (varimax rotation with Kaiser normalisation) of the 11 items on political participation mentioned in Table 2. Loadings stronger than .60 are reported in bold. The extracted dimensions are: 1. Voting, 2. Influencing, 3. Protesting.

The results so far can be concluded by saying that older adults in Scandinavia are active voters but less active between elections, that there are no major differences between Finland and Sweden in this respect, and that engagement rates in general are lower among older age groups, especially when it comes to non-institutionalised participation. The descriptive analysis has thus generated some support for the first hypothesis. This brings us to the second hypothesis, which asserted that political participation of older Scandinavians can be explained mainly by their individual resources according to the resource theory of civic voluntarism (Verba et al. 1995). This hypothesis was tested by comparing the relative explanative power of resource-theory variables on three different types of political participation to that of other individual-level characteristics as well as contextual factors (cf. Table 1). Table 4 reports the results from multi-level logistic regressions for the outcome variable 
voting, which is a dichotomised variable based on the first dimension that was extracted in Table 3.

Model 0, which separates level-1 variance from variance resting on the municipal and country level, shows that only a tiny proportion (below 1\%) of the total variance originates from the contextual level. Model 1 juxtaposes resource-theory variables, civic attitudes as well as well-being variables, respectively. It shows support for the resource theory by displaying a strong influence from resource-theory variables while effects of civic attitudes and well-being were mostly weak or non-existing, except for the variable oldage attitude. Religiosity and health were only weakly associated with voting whereas no visible effect at all was found for sense of duty, quality of life and health care trust.

The absent effect of sense of duty on voting is interesting when considering its strong impact on voting in previous research (Goerres 2009). Similarly, the non-existent effect of quality of life offers no support for the claims made elsewhere about a link between a person's wellbeing and voting (e.g. Schyns 1998; Veenhoven 1995). Allegedly, wealthy, welleducated, politically integrated and socially embedded older adults experiencing a negative attitude towards older people in politics are more likely to vote than others. Interestingly, political efficacy played only a marginal role and interpersonal trust had no role at all. Model 2, which includes three municipal-level predictors, showed a weak but significant effect of political structure indicating that municipalities with a more rightist ideological identification in general increases the likelihood for voting. However, in the full model (model 3) that also includes control variables the effect of contextual political structure vanished while the effects from the individual-level predictors remained strong. We also found strong positive effects of control variables, such as civil status and duration of residence, which indicate that older adults living with a partner and with a residential duration over 20 years are more likely to vote than others.

By and large, Table 4 supports the resource theory and earlier findings (e.g. Goerres 2009; Nygård \& Jakobsson 2011) by indicating that individual-level socio-economic resources, engagement and social networks largely explain voting among older Scandinavian adults, but it also shows that negative attitudes towards older adults in politics as well as 
International Journal of Ageing and Later Life

Table 4. The effect of individual- and municipal-level variables on voting

\begin{tabular}{|c|c|c|c|c|}
\hline Variables & $\begin{array}{c}\text { Model } 0 \\
\beta \text { (S.E.) }\end{array}$ & $\begin{array}{c}\text { Model } 1 \\
\beta \text { (S.E.) }\end{array}$ & $\begin{array}{c}\text { Model } 2 \\
\beta \text { (S.E.) }\end{array}$ & $\begin{array}{c}\text { Model } 3 \\
\beta \text { (S.E.) }\end{array}$ \\
\hline \multicolumn{5}{|c|}{ Individual level (level 1) } \\
\hline Constant & $1.48(.04)^{* * *}$ & $-4.77(.53)^{* * *}$ & $1.50(.06)^{* * *}$ & $-5.47(.68)^{* * *}$ \\
\hline Income & & $.48(.10)^{* * *}$ & & $.51(.12)^{* * *}$ \\
\hline Education & & $.53(.10)^{* * *}$ & & $.50(.10)^{* * *}$ \\
\hline Pol. trust & & $.47(.15)^{* *}$ & & $.51(.16)^{* *}$ \\
\hline Pol. efficacy & & $.17(.10) \dagger$ & & $.18(.10) \dagger$ \\
\hline Party member & & $1.13(.16)^{* * *}$ & & $1.23(.17)^{* * *}$ \\
\hline Pol. interest & & $.35(.17)^{*}$ & & $.36(.18)^{*}$ \\
\hline Vol. associations & & $.64(.13)^{\star * *}$ & & $.69(.15)^{* * *}$ \\
\hline Interpersonal trust & & $.09(.10)$ & & $.04(.11)$ \\
\hline Sense of duty & & $.14(.10)$ & & $.14(.11)$ \\
\hline Religiosity & & $.17(.10) \dagger$ & & $.19(.11) \dagger$ \\
\hline Life quality & & $.12(.11)$ & & $.07(.12)$ \\
\hline Self-rated health & & $.19(.10) \dagger$ & & $.13(.11)$ \\
\hline Health care trust & & $.00(.10)$ & & $.00(.10)$ \\
\hline Old-age attitude & & $.26(.10)^{* *}$ & & $.31(.10)^{* *}$ \\
\hline Age & & & & $-.01(.05)$ \\
\hline Male gender & & & & $-.11(.11)$ \\
\hline Language & & & & $-.27(.16) \dagger$ \\
\hline Civil status & & & & $.30(.11)^{* *}$ \\
\hline Residence & & & & $.33(.12)^{* *}$ \\
\hline \multicolumn{5}{|c|}{ Municipal level (level 2) } \\
\hline Vol. associations & & & $<.001$ & $<.001$ \\
\hline Pol. structure & & & $.002(.001)^{*}$ & $.001(.001)$ \\
\hline Old-age attitude & & & $<.001$ & $<.001$ \\
\hline$\sigma_{\mathrm{u}}^{2}$ & $.015(.012)$ & $.034(.029)$ & $<.001$ & $<.001$ \\
\hline$V P C$ & .004 & & & \\
\hline AIC & 6582.505 & 3196.394 & 8508.745 & 2844.735 \\
\hline
\end{tabular}

Note. Two-level random-intercept logistic regression models with 6838 persons nested in 32 municipalities.

The table presents non-standardised $\beta$ estimates (standard errors in parentheses) and significance levels $(p) . \sigma_{\mathrm{u}}^{2}$ represents the variance residing on level 2 (municipal level) and VPC is the variance partition coefficient (intra-class correlations coefficient) that shows the total variance residing on the municipal level. The outcome variable is dichotomous (estimated category: voted in all three latest elections). ${ }^{* * *} p<0.001 .{ }^{* *} p<0.01 .{ }^{*} p<0.05$. $\dagger p<0.10$.

All individual-level predictors are dichotomised with the lower value as reference category (cf. Table 1). Male gender is a dummy variable (woman = ref.) and age is treated as a linear variable. All municipal-level predictors are linear variables. 
long-term residence with a partner influences voting (cf. Campbell 2003; Goerres 2009). Interestingly, almost no variance was found to be residing on the contextual level, which also explains why the full model (model 3) provided the best fit. No significant individual-level or cross-level interaction effect were detected.

Table 5 reports the results for influencing. Model 0 reveals a somewhat higher proportion of variance residing on the municipal level (approximately $2 \%$ ) than in the case of voting. Also, here we could find strong effects of socio-economic resources like education, engagement variables, for example party membership, and mobilisation variables such as membership in voluntary organisations. But in relation to voting, older adults' engagement in influencing could be explained somewhat less by resource-theory variables and somewhat more by civic attitudes and wellbeing variables. No significant effects of political trust or political efficacy could be found, but instead strong effects of religiosity, health care trust and the prevalence of negative attitudes towards older adults within politics were found. This suggests that influencing partly follows another action rationale than voting, and that civic attitudes or sentiments of disadvantage or ageism are more likely to trigger this kind of participation than voting (Campbell 2003). Model 2 indicates only insignificant effects of contextual-level variables and model 3, in turn, shows that the strong effects of individual-level characteristics remain when control variables and contextual-level variables are controlled for. But we can also see that most of the control variables are strongly associated with influencing suggesting that influencing is more common among younger Swedishspeaking males with less than 20 years of residential duration. Also for this variable, the full model provides the best fit, but we also found negative cross-level interaction effects for individual-level old-age attitude and voluntary association membership and their municipal-level analogues, as well as between individual-level religiosity and municipal-level political structure (not reported in Table 5). Although these interactions did not have an impact on the overall model fit, they suggest that contextual factors influence political behaviour of older adults to some extent.

Table 6 reports the results for protesting. Model 0 indicates that approximately $2 \%$ of the total variation resides on the municipal level. In model 1 we once again found some support for the resource theory 
International Journal of Ageing and Later Life

Table 5. The effect of individual- and municipal-level variables on influencing

\begin{tabular}{|c|c|c|c|c|}
\hline Variables & $\begin{array}{c}\text { Model } 0 \\
\beta \text { (S.E.) }\end{array}$ & $\begin{array}{c}\text { Model } 1 \\
\beta \text { (S.E.) }\end{array}$ & $\begin{array}{c}\text { Model } 2 \\
\beta \text { (S.E.) }\end{array}$ & $\begin{array}{c}\text { Model } 3 \\
\beta \text { (S.E.) }\end{array}$ \\
\hline \multicolumn{5}{|c|}{ Individual level (level 1) } \\
\hline Constant & $-.82(.06)^{* * *}$ & $-4.16(.42)^{* * *}$ & $-0.83(.11)^{* * *}$ & $-2.22(.50)^{* * *}$ \\
\hline Income & & $.47(.09)^{* * *}$ & & $.25(.09)^{* *}$ \\
\hline Education & & $.59(.07)^{* * *}$ & & $.53(.08)^{* * *}$ \\
\hline Pol. trust & & $.01(.09)$ & & $.03(.09)$ \\
\hline Pol. efficacy & & $.55(.07)^{* * *}$ & & $.56(.08)^{* * *}$ \\
\hline Party member & & $.65(.08)^{* * *}$ & & $.58(.08)^{* * *}$ \\
\hline Pol. interest & & $-.16(.14)$ & & $-.07(.15)$ \\
\hline Vol. associations & & $.50(.08)^{* * *}$ & & $.51(.08)^{* * *}$ \\
\hline Interpers. trust & & $.04(.08)$ & & $.04(.08)$ \\
\hline Sense of duty & & $.07(.07)$ & & $.07(.08)$ \\
\hline Religiosity & & $-.24(.08)^{* *}$ & & $-.16(.08)^{*}$ \\
\hline Life quality & & $.09(.08)$ & & $.00(.08)$ \\
\hline Self-rated health & & $-.05(.08)$ & & $-.08(.08)$ \\
\hline Health care trust & & $-.28(.07)^{* * *}$ & & $-.21(.07)^{* *}$ \\
\hline Old-age attitude & & $.27(.07)^{* * *}$ & & $.28(.07)^{* * *}$ \\
\hline Age & & & & $-.19(.04)^{* * *}$ \\
\hline Male gender & & & & $.42(.08)^{* * *}$ \\
\hline Language & & & & $-.85(.10)^{* * *}$ \\
\hline Civil status & & & & $-.09(.09)$ \\
\hline Residence & & & & $-.40(.09)^{* * *}$ \\
\hline \multicolumn{5}{|c|}{ Municipal level (level 2) } \\
\hline Vol. associations & & & $<.001$ & $<.001$ \\
\hline Pol. structure & & & $.005(.008)$ & $<.001$ \\
\hline Old-age attitude & & & $<.001$ & $<.001$ \\
\hline$\sigma_{u}^{2}$ & $.067(.027)$ & $.092(.040)$ & $.021(.274)$ & $<.001$ \\
\hline$V P C$ & .0198 & & & \\
\hline AIC & 8469.32 & 5221.063 & 8312.214 & 4656.871 \\
\hline
\end{tabular}

Note. Two-level random-intercept logistic regression models with 6838 persons nested in 32 municipalities.

The table presents non-standardised $\beta$ estimates (standard errors in parentheses) and significance levels $(p) . \sigma_{\mathrm{u}}^{2}$ represents the variance residing on level 2 (municipal level) and VPC is the variance partition coefficient (intra-class correlations coefficient) that shows the total variance residing on the municipal level. The outcome variable is dichotomous (estimated category: participated in at least one activity during the latest 5-year period). ${ }^{* * *} p<0.001 .{ }^{* *} p<0.01 .{ }^{*} p<0.05 . p<0.10$.

All individual-level predictors are dichotomised with the lower value as reference category (cf. Table 1). Male gender is a dummy variable (woman = ref.) and age is treated as a linear variable. All municipal-level predictors are linear variables. 
since strong positive effects of income, education, party membership, membership in voluntary organisations as well as interpersonal trust could be detected. But also strong effects of civic attitudes and well-being could be found, which indicates that the dominance of resource-related explanations is far from unchallenged. Also a person's religiosity, trust in health care and experiences of negative attitudes towards older adults explain why they engage in protesting. This means that it is not only welloff, well-educated, party members with large social networks and high interpersonal trust that tend to engage in protesting, but also non-religious older adults with low trust in health care and experiences of negative oldage attitudes. Also here, the action rationale seems to be different to that of voting, since civic attitudes as well as perceived threats to the supply of welfare-state services (e.g. health care services) are likely to set off this kind of participation. Interestingly still, model 2, which examines the effects of only municipal-level variables, shows that the inclination to protest is positively associated with the overall ideological structure of the municipalities. The more right-wing a municipality, the stronger the inclination to protest tends to be. The inclusion of control variables in the full model (model 3) reveals a negative relationship with age, male gender, language and residence. The propensity for engaging in protest activities was consequently higher among 65-year-olds, women, Swedish-speakers as well as persons with a shorter residential duration. We also found that municipal-level membership in voluntary associations was positively related to protesting, which suggests that older adults in municipalities with a higher average engagement in voluntary associations generally are keener on protesting. However, a negative interaction effect was found between aggregated membership in voluntary associations and its individual-level analogue as well as between municipal-level political structure and individual-level religiosity (not reported in the Table 6).

Although an inclusion of these interaction terms did not affect the overall fit of the model they suggest that protesting is less common among socially connected older adults living in municipalities with a lower average level of associational membership, as well as for non-religious persons living in municipalities with an overall rightist ideological structure. 
International Journal of Ageing and Later Life

Table 6. The effect of individual- and municipal-level variables on protesting

\begin{tabular}{|c|c|c|c|c|}
\hline Variables & $\begin{array}{l}\text { Model } 0 . \\
\beta \text { (S.E.) }\end{array}$ & $\begin{array}{l}\text { Model } 1 \\
\beta \text { (S.E.) }\end{array}$ & $\begin{array}{l}\text { Model } 2 \\
\beta \text { (S.E.) }\end{array}$ & $\begin{array}{l}\text { Model } 3 \\
\beta \text { (S.E.) }\end{array}$ \\
\hline \multicolumn{5}{|c|}{ Individual level (level 1) } \\
\hline Constant & $-.60(.05)^{* * *}$ & $-4.49(.41)^{* * *}$ & $-0.54(.08)^{* * *}$ & $-3.04(.51)^{\star * *}$ \\
\hline Income & & $.29(.08)^{* * *}$ & & $.36(.09)^{* * *}$ \\
\hline Education & & $.58(.07)^{* * *}$ & & $.44(.07)^{\star * *}$ \\
\hline Pol. Trust & & $.00(.09)$ & & $.03(.09)$ \\
\hline Pol. efficacy & & $.09(.07)$ & & $.09(.07)$ \\
\hline Party member & & $.62(.08)^{* * *}$ & & $.67(.08)^{* * *}$ \\
\hline Pol. interest & & $.11(.14)$ & & $.21(.15)$ \\
\hline Vol. associations & & $.55(.08)^{* \star *}$ & & $.55(.08)^{* * *}$ \\
\hline Interp. trust & & $.25(.08)^{* *}$ & & $.21(.08)^{* *}$ \\
\hline Sense of duty & & $.07(.07)$ & & $.02(.08)$ \\
\hline Religiosity & & $-.16(.08)^{*}$ & & $-.16(.08)^{*}$ \\
\hline Life quality & & $.08(.07)$ & & $.07(.08)$ \\
\hline Self-rated health & & $.17(.07)^{*}$ & & $.15(.08) \dagger$ \\
\hline Health care trust & & $-.25(.07)^{* * *}$ & & $-.20(.07)^{* *}$ \\
\hline Old-age attitude & & $.46(.07)^{* * *}$ & & $.50(.07)^{* * *}$ \\
\hline Age & & & & $-.16(.03)^{* * *}$ \\
\hline Male gender & & & & $-.26(.07)^{* *}$ \\
\hline Language & & & & $-.53(.11)^{* * *}$ \\
\hline Civil status & & & & $.11(.09)$ \\
\hline Residence & & & & $-.23(.09)^{*}$ \\
\hline \multicolumn{5}{|c|}{ Municipal level (level 2) } \\
\hline Vol. associations & & & $<.001$ & $.011(.005)^{*}$ \\
\hline Pol. structure & & & $.005(.001)^{*}$ & $<.001$ \\
\hline Old-age attitude & & & $<.001$ & $<.001$ \\
\hline$\sigma_{\mathrm{u}}^{2}$ & $.070(.026)^{*}$ & $.086(.035)^{*}$ & $<.001$ & $<.001$ \\
\hline$V P C$ & .021 & & & \\
\hline AIC & 8964.767 & 5507.057 & 8854.065 & 4967.85 \\
\hline
\end{tabular}

Note. Two-level random-intercept logistic regression models with 6838 persons nested in 32 municipalities.

The table presents non-standardised $\beta$ estimates (standard errors in parentheses) and significance levels $(p) . \sigma_{\mathrm{u}}^{2}$ represents the variance residing on level 2 (municipal level) and VPC is the variance partition coefficient (intra-class correlations coefficient) that shows the total variance residing on the municipal level. The outcome variable is dichotomous (estimated category: participated in at least one activity during the latest 5 -year period). ${ }^{* * *} p<0.001 .{ }^{* *} p<0.01 .{ }^{*} p<0.05 . \dagger p<0.10$.

All individual-level predictors are dichotomised with the lower value as reference category (cf. Table 1). Male gender is a dummy variable (woman = ref.) and age is treated as a linear variable. All municipal-level predictors are linear variables. 
Political participation of older adults in Scandinavia

\section{Conclusions and Discussion}

The article set out to examine political participation among older adults in two Scandinavian countries. Two specific hypotheses were tested, the first being that older adults are loyal voters but less avid to engage in politics between elections, and the second that individual-level characteristics pertaining to the resource theory of civic voluntarism (Verba et al. 1995) explain why older people participate in politics. Two major conclusions can be drawn from the analyses.

First, as to the question of patterns of political participation, we find that the analyses largely tend to support the first hypothesis, since older Scandinavian adults report a high activity in terms of institutionalised participation but considerably lower activity regarding non-institutionalised participation. This pattern was found for both Finnish and Swedish elders, although the latter group was somewhat more active between elections than the former. We also found an overall negative correlation between age and participation in both countries. Political engagement is generally lower in older age groups, but this holds for non-institutionalised participation to a much greater extent than institutionalised participation. We should not, however, exaggerate the significance of the reported differences between institutionalised and non-institutionalised participation, since it is well known that voting is generally overestimated while, for example, protesting tends to be underestimated (cf. Martikainen et al. 2005). Moreover the results do not provide an altogether unequivocal picture of older Scandinavians as political beings, since we found non-institutionalised participation to be relatively high in some sub-groups (such as persons in their 60s living in Sweden) while some of the older adults had reported refraining from political participation whatsoever.

Furthermore, we found that political participation of older Scandinavians tends to be structured according to three dimensions that we have named voting, influencing and protesting. These dimensions not only suggest that persons who engage in one type of activity also tend to be active in other similar ones (Bengtsson \& Christensen 2009; Verba et al. 1978), but they also tend to have somewhat different rationales as well as determinants. For example, protest activities are more common among 65-year-old, well-educated (female) persons and are more likely to be 
International Journal of Ageing and Later Life

triggered by some kind of perceived hardship or threat in terms of for example cuts in pensions or welfare-state services to older people (Campbell 2002, 2003), while voting is not structured so much according to age or gender but more squarely to individual-level resources, such as high education, political integration or social networks. A good example of this kind of "protest" activity is boycotting, which can be interpreted as an expression of a more individualised and "consumerist" way of influencing society than traditional influencing within the boundaries of representative democracy (Inglehart \& Norris 2003; Stolle \& Micheletti 2006; Stolle et al. 2005). In a way, it represents a rather uncomplicated way of "voting with one's feet". Influencing, in turn, is characterised more by a passive disposition of disapproval rather than open manifestations of protest, which means that persons engaging in this form of political action are not very likely to take to the streets in order to protest against or influence policies; instead they tend to work the system from within, that is, to contact elected politicians, to use the legal system or to ventilate their views in newspaper columns. These results can be said to be in concordance with previous studies (e.g. Burr et al. 2002; Goerres 2007, 2009).

The second conclusion relates to the explanative performance of the civic voluntarism model when applied on older adults in a Scandinavian setting. As shown in Tables 4-6 the model performs rather well in relation to other sets of variables when it comes to predicting political participation of older people. Individual-level "participatory resources" such as education, party membership and membership in voluntary associations are important predictors for all three types of political participation. But it is also clear that the explanative power of the model differs between different types of political participation. It performs somewhat better with regard to voting than non-institutionalised participation, which can be attributed to the fact that influencing and protesting follow other action rationales than voting (cf. Nygård \& Jakobsson 2011). In these two cases we found that other variables challenge the dominance of the resource theory, notably the religiosity, health care trust and sentiments of negative attitudes towards older people, play an important role. Moreover, contextual variables had a somewhat stronger impact on influencing and protesting than voting. The difficulty in finding level-two effects for voting and influencing is likely 
due to a small sample size in combination with a small municipal-level variance. Given this, it is also not surprising that the cross-level interactions did not reach statistical significance.

Therefore, we can perhaps conclude that although the resource model performs fairly well in explaining political participation of older Scandinavian adults, we need also to consider other kinds of participatory factors on both the individual and contextual level such as the overall well-being of older adults or ageist structures in society.

The exceptionally high voting participation reported here may reflect a strong sense of duty among older Scandinavians in general, which in turn can be traced back to their political socialisation. As turnout rates were relatively high in the early 1950s and early 1960s and voting was generally conceived of as a moral obligation, this may have left a lasting imprint on the first-time voters at that time (Franklin 2004; Rose \& McAllister 1990). Moreover, we need to consider the possible effects of the welfare-state system in these two countries. It is possible that the strong effect of negative old-age attitudes and health care trust reflects some kind of worry in relation to country-specific cutbacks in old-age pensions or welfare services for older adults (Campbell 2002, 2003).

The findings found in this article have several practical implications. One is the insight that older Scandinavians are indeed very active citizens and that they therefore constitute a powerful category of the electorate (cf. Myles \& Pierson 2001; Schulz \& Binstock 2006). Whether or not this will have an effect of the overall inter-generational power balance in Finland and Sweden remains unclear, but it is likely to play a significant role when welfare state reforms are scheduled and cuts in pensions or services to older adults are considered. Another implication is that the high activity found here may have a positive effect on the overall inclusiveness and wellbeing of older adults, and thus help to sustain the popular visions of active ageing (e.g. Hoskins \& Mascherini 2009; Walker 2006).

\section{Acknowledgements}

This work was supported financially by the European Union through its Interreg program Botnia Atlantica, the Regional Council of Ostrobothnia (Finland), the town of Umeå (Sweden), as well as the Gerda project partners Åbo Akademi University (Finland), Novia University of Applied 
International Journal of Ageing and Later Life

Sciences (Finland) and Umeå University (Sweden). This support is warmly acknowledged.

\section{Corresponding Author}

Mikael Nygård, Department of Social Sciences, Åbo Akademi University, Box 311m 65101 Vasa, Finland. Email: mikael.nygard@abo.fi

\section{References}

Anttonen, A. (2005). Empowering social policy: The role of social care services in modern welfare states. In J. Palme \& O. Kangas (eds.), Social Policy and Economic Development in the Nordic Countries (pp. 88-117). Basingstoke: Palgrave Macmillan.

Bäck, M. (2011). Socialt kapital och politiskt deltagande i Europa [Social capital and political participation in Europe]. PhD Thesis September 2011. Åbo: Åbo University Press.

Barnes, S. H., Kaase, M., Allerbeck, K. R., Farah, B. G., Heunks, F., Inglehart, R., Jennings, M. K., Klingemann, H-D., Marsh, A. \& Rosenmayer, L. (1979). Political Action: Mass Participation in Five Western Democracies. Beverly Hills, CA: Sage.

Bengtsson, Å. \& Christensen, H. S. (2009). Politiskt deltagande i Finland spridning och drivkrafter [Political participation in Finland - patterns and determinants]. Politiikka 51(2): 77-95.

Blais, A., Gidengil, E., Nevitte, N. \& Nadeau, R. (2004). Where does turnout decline come from? European Journal of Political Research 43(2): 221-236.

Bohrnstedt, G. W. \& Knoke, D. (1982). Statistics for Social Data Analysis. Itasca, IL: F. E. Peacock Publishers.

Burr, J. A., Caro, F. G. \& Moorhead, J. (2002). Productive aging and civic participation. Journal of Aging Studies 16(1): 87-105.

Butler, D. \& Stokes, D. (1983). Political Change in Britain. The Evolution of Electoral Choice. Basingstoke: Macmillan.

Campbell, A. L. (2002). Self-interest, social security, and the distinctive participation patterns of senior citizens. American Political Science Review 96(3): 565-574. 
Political participation of older adults in Scandinavia

Campbell, A. L. (2003). How Politics Make Citizens: Senior Political Activism and the American Welfare State. Princeton, NJ: Princeton University Press.

Cuddy, A. J., Norton, I. N. \& Fiske, S. T. (2005). This old stereotype: The pervasiveness and persistence of the elderly stereotype. Journal of Social Issues 62(1): 267-285.

Cutler, N. E. (1977). Demographic, socio-psychological, and political factors in the politics of aging: A foundation for research in "political gerontology". American Political Science Review 71(3): 1011-1025.

Dalton, R. J. (2004). Democratic Challenges, Democratic Choices. The Erosion of Political Support in Advanced Industrial Democracies. Oxford: Oxford University Press.

Dalton, R. J. (2006). Citizen Politics: Public Opinion and Political Parties in Advanced Industrial Democracies. Washington DC: Congressional Quarterly Press.

Dalton, R. J. (2008). The Good Citizen: How a Younger Generation Is Reshaping American Politics. Washington, DC: Congressional Quarterly Press.

Easton, D. (1975). A reassessment of the concept of political support. The British Journal of Political Science 5(4): 435-457.

Einhorn, E. \& Logue, J. (2003). Modern Welfare States: Scandinavian Politics and Policy in the Global Age. Westport: Praeger.

Franklin, M. N. (2004). Voter Turnout and the Dynamics of Electoral Competition in Established Democracies since 1945. New York: Cambridge University Press.

Frey, B. S., Benz, M. \& Stutzer, A. (2004). Introducing procedural utility: Not only what, but also how matters. Journal of Institutional and Theoretical Economics 160(3): 377-401.

GERDA. (2012). The GERDA Botnia Project. Available on: http://web. novia.fi/gerda/ (Accessed: February 25, 2012)

Goerres, A. (2007). Why are older people more likely to vote? The impact of ageing on electoral turnout in Europe. British Journal of Politics and International Relations 9(1): 90-121.

Goerres, A. (2009). The Political Participation of Older People in Europe: The Greying of Our Democracies. Basingstoke: Palgrave Macmillan.

Goerres, A. (2010). Being less active and outnumbered? The political participation and relative pressure potential of young people in 
International Journal of Ageing and Later Life

Europe. In J. C. Tremmel (ed.), A Young Generation Under Pressure? (pp. 207-224). Berlin: Springer Verlag.

Herberts, K. (2011). Gerda-enkäten [The Gerda survey]. Vasa: Novia University of Applied Sciences.

Hoskins, B. L. \& Mascherini, M. (2009). Measuring active citizenship through the development of a composite indicator. Social Indicators Research 90(3): 459-488.

Inglehart, R. (1990). Culture Shift in Advanced Industrial Society. Princeton: Princeton University Press.

Inglehart, R. \& Norris, P. (2003). Rising Tide: Gender Equality and Cultural Change around the World. Cambridge: Cambridge University Press.

Jennings, M. K. \& Markus, G. B. (1988). Political involvement in the later years: A longitudinal survey. American Journal of Political Science 32(2): 302-316.

Kaase, M. (1999). Interpersonal trust, political trust and non-institutionalised political participation in Western Europe. West European Politics 22(3): 1-21.

Kam, P-K. (2000). Political disempowerment among older people in Hong Kong. Journal of Cross-Cultural Gerontology 15(4): 307-329.

Lane, R. E. (1988). Procedural goods in a democracy: How one is treated versus what one gets. Social Justice Research 2(3): 177-192.

Martikainen, P., Martikainen, T. \& Wass, H. (2005). The effect of socioeconomic factors on voter turnout in Finland: A register-based study of 2.9 million voters. European Journal of Political Research 44(5): 645-669.

McManus, S. A. (1996). Young v. Old: Generational Combat in the 21st Century. Boulder, Colorado: Westview Press.

Myles, J. \& Pierson, P. (2001). The comparative political economy of pension reform. In P. Pierson (ed.), The New Politics of the Welfare State (pp. 305-333). Oxford: Oxford University Press.

NCM [Nordic Council of Ministers] (2010). Nordic Statistical Yearbook 2010. Copenhagen: Nordic Council of Ministers.

Norris, P. (2002). Democratic Phoenix: Reinventing Political Activism. Cambridge: Cambridge University Press.

Nousiainen, J. (1998). Suomen poliittinen järjestelmä [The political system of Finland]. Juva: WSOY. 
Nygård, M. \& Jakobsson, G. (2011). Senior citizens and political participation- evidence from a Finnish regional study. Ageing $\mathcal{E}$ Society 33(1): First View, 1-12, doi: 10.1017/S0144686X11001139.

Putnam, R. (2000). Bowling Alone: The Collapse and Revival of American Community. New York: Simon and Schuster.

Quintelier, E. (2007). Differences in political participation between young and old people. Contemporary Politics 13(2): 165-180.

Rose, R. \& McAllister, I. (1990). The Loyalties of Voters: A Lifetime Learning Model. Newbury Park, CA: Sage.

Rosenstone, S. J. \& Hansen, J. M. (1993). Mobilization, Participation, and Democracy in America. New York: Macmillan.

Schulz, J. H. \& Binstock, R. H. (2006). Ageing Nation: The Economics and Politics of Growing Older in America. Westport, CT: Praeger.

Schyns, P. (1998). Crossnational differenes in happiness: Economic and cultural factors explored. Social Indicators Research 43(1): 3-26.

Smeeding, T. M. \& Sandström, S. (2005). Poverty and Income Maintenance in Old Age: A Cross-National View of Low Income Older Women. Luxembourg Income Study Working Paper Series, Working Paper No. 398.

Snijders, T. \& Bosker, R. J. (2001). Multilevel Analysis: An Introduction to Basic and advanced Multilevel Modeling. Thousand Oaks, CA: Sage.

Stolle, D., Hooghe, M. \& Micheletti, M. (2005). Politics in the supermarket: Political consumerism as a form of political participation. International Political Science Review 26(3): 245-269.

Stolle, D. \& Micheletti, M. (2006). The gender gap reversed: Political consumerism as a women-friendly form of civic and political engagement. In X. O'Neill \& X. Gidengill (eds.), Gender and Social Capital (pp. 45-70). New York: Routledge.

Stutzer, A. \& Frey, B. S. (2006). Political participation and procedural utility: An empirical study. European Journal of Political Research 45(3): 391-418.

Sundström, G. (2009). Demography of Aging in the Nordic Countries. In P. Uhlenberg (ed.), International Handbook of Population Aging (pp. 91-111). London: Springer.

Teorell, J. (2003). Linking social capital to political participation: Voluntary associations and networks of recruitment in Sweden. Scandinavian Political Studies 26(1): 49-66. 
International Journal of Ageing and Later Life

Veenhoven, R. (1995). The cross-national pattern of happiness: Test of predicitions implied in three theories of happiness. Social Indicators Research 34(1): 33-68.

Verba, S. \& Nie, N. H. (1972). Participation in America: Political Democracy and Social Equality. New York: Harper and Row.

Verba, S., Nie, N. H. \& Kim, J- O. (1978). The Modes of Democratic Participation: A Cross-National Comparison. Beverly Hills, CA: Sage.

Verba, S., Schlozman, K. L. \& Brady, H. E. (1995). Voice and Equality: Civic Voluntarism in American Politics. Cambridge: Harvard University Press.

Walker, A. (2006). Active ageing in employment: Its meaning and potential. Asia-Pacific Review 13(1): 78-93.

Wass, H. (2008). Generations and turnout. The generational effect in electoral participation in Finland. PhD Thesis June 2008. Acta Politica 35. Helsinki: Helsinki University Press.

Welch, S. (1977). Women as political animals? A test of some explanations for male-female political participation differences. American Journal of Political Science 21(4): 711-730.

Westerhof, G. J. \& Tulle, E. (2011). Meanings of ageing and old age: Discursive contexts, social attitudes and persona identities. In J. Bond, S. Peace, F. Dittmann-Kohli \& G. Westerhof (eds.), Ageing in Society (pp. 235-254). London: Sage.

Wilson, G. (2000). Understanding Old Age. London: Sage.

Wolfinger, R. E. \& Rosenstone, S. J. (1980). Who Votes? New Haven, CT: Yale University Press. 